\title{
Santa Fosca in Torcello and the Middle Byzantine Churches in Eastern Greece: Preliminary Comparison and Remarks on Common Features and Differences
}

\begin{abstract}
By Antonella Manzo*
The main aim of this work is to critically examine Santa Fosca building period through the analysis of the similarities as well as the differences with some churches located in Greece and belonging to the so-called octagonal domed type. In fact, since the second half of the Nineteenth century a historiographical tradition has compared Santa Fosca with these Greek Middle-Byzantine churches, where eight supports, piers or columns, arranged in a regular or irregular octagon, receive the loads from the cupola. The comparison is based on the direct analysis of these buildings: the structural configuration, the constructive materials and techniques as well as the affinities in decoration, occurring both inside and outside, are under investigation. This contribution offers a new perspective, from which it could be possible to study the period of erection of the Venetian church, a topic that is still object of debate among the scientific community.
\end{abstract}

\section{Introduction}

Torcello is an island belonging to the Northern Venetian Laguna, which lives its golden age during the X-XI century AD: in his Administrando Imperio of 927 Constantine VII Porphyrogenitus defines Torcello as emporion mega, to testify the great importance of its intense trades with the Orient.

The church of Santa Fosca is located on the island at the Southern side of the ancient Basilica of Santa Maria Assunta, whose origins date back to the inscription of $639 \mathrm{AD}$, discovered during the excavations of 1895. On the contrary, the period of Santa Fosca erection is still unknown, although it is assumed to be around IX and XI century.

Because of the uniqueness of the whole complex, as well as the singularity of the church structural system and of its constructive elements, this Italian architectural monument can be defined as a unicum. Specifically, its main peculiarity is the transition from the central square plan to the octagonal organization of the supports and finally to the circular base of the drum through the presence of uncommon couples of pendentives.

Several authors have identified some analogies between Santa Fosca and a group of churches, which developed in Greece during the Middle-Byzantine period. In fact, they show the same peculiarity that occurs in the Venetian church: the transition from the square to the circle throughout the octagonal

${ }^{*} \mathrm{PhD}$ Student, Polytechnic University of Milan, Italy. 
disposition of the supports. Just for this reason, this specific typology is called "octagonal domed type".

Some of the most important scholars that refer to this comparison are mentioned below. Already in 1847, Pietro Selvatico assumes that Santa Fosca has Oriental origins, due to the particular structural organization and the Greek cross plan ${ }^{1}$. When the French travelers of the XIX century describe the Venetian church after their rout to Torcello, they find very strong connections with the Greek Byzantine monuments: according to Edouard Charton, the church plan surely belongs to the XI century and is a Byzantine one ${ }^{2}$. Edouard Corroyer also finds analogies with the Greek churches, and his description is even more detailed: according to him, its Oriental influences can be found both analyzing the church of the Soteira Lykodemou at Athens and the main church of Daphni Monastery, located on the way from Athens to the ancient Eleusis ${ }^{3}$. Although their hypotheses are coherent with the aim of this research, their assumptions have to be further analyzed in order to contextualize them to the period of their elaboration.

More recently, Sergio Bettini ${ }^{4}$ has assumed that the Venetian monument can be better compared with the Basilica of the Transfiguration of Christ in Triphylia. While according to Richard Krautheimer also, in Santa Fosca many similarities occur with the Soteira Lykodemou ${ }^{5}$.

Giovanni Lorenzoni, citing both the abovementioned authors, finds more analogies with the church of Hosios Loukas in Phocis ${ }^{6}$, whereas Joan Olivia Richardson sees some connections even with the Monastery of Nea Moni on Chios ${ }^{7}$.

On the other hand, even scholars involved in the examination of the Greek monuments of the octagonal type refer to Santa Fosca in their studies: Gabriel Millet compares the Daphni Monastery he was studying with other churches of

1. Pietro Selvatico, Sulla architettura e sulla scultura in Venezia [About architecture and sculpture in Venice] (Venice: P. R. Carpano Editore, 1847), 29-30.

2. According to Charton the Venetian monument results a "charmante et curieuse église du onzième siècle, construite sur un plan entièrement byzantin". Edouard Charton, "Les Eglises de Torcello" [The churches of Torcello], Le Magasin Pittoresque XL Anne (1872): 97-99.

3. Edouard Corroyer, L'Architecture Romane [The Romanic architecture] (Paris: Sociétè Francaise d'Edition d'Art, 1888), 126-136.

4. Sergio Bettini, "Aspetti bizantineggianti dell'architettura di Torcello" [Byzantine features of the architecture of Torcello] in Torcello, ed. Mario Brunetti et al. (Venice: Libreria Serenissima Editrice, 1940), 54-55.

5. Richard Krautheimer, Early Christian and Byzantine Architecture (Harmondsworth: The Pelican History of Art, 1965), 287.

6. Giovanni Lorenzoni, "Santa Fosca di Torcello nell'ambito architettonico orseoliano" [Santa Fosca of Torcello in the Orseolian architectural field], in Storia dell'arte marciana: l'architettura, ed. Renato Polacco (Venice: Marsilio Editori, 1997), 127. Lorenzoni justifies its hypothesis referring to the arrival in Torcello of Greek artisans, who had to work on the Basilica decorations, very similar to the golden mosaics we can admire in Hosios Loukas.

7. Joan Olivia Richardson, "Elementi bizantini nell'architettura delle chiese di San Marco, di Santa Fosca di Torcello e del Duomo di Jesolo" [Byzantine elements in the church architecture of Saint Mark, Santa Fosca of Torcello and the Dome of Jesolo], in Storia dell'arte marciana: l'architettura, ed. Renato Polacco (Venice: Marsilio Editori, 1997), 180-181. 
the same type, among which he mentions Santa Fosca in Torcello ${ }^{8}$. Eustathios Stikas also, in his essay about the church of the Transfiguration of Christ in Triphylia ${ }^{9}$, cites Santa Fosca as Italian case of the octagonal dome typology.

Hence, in the frame of this work, the analogies and differences that occur between Santa Fosca and the Greek monuments want to be analysed, in order to verify, through a general outline, the reliability of this significant parallelism existing in literature. This is achieved through the analysis of the most evident characteristics of these churches such as the structural configuration, the construction materials, and the decoration that appear both outside and inside these monuments. Taking into account this parallelism, it is hence possible to give some information more about Santa Fosca origins: as Buchwald ${ }^{10}$ has already stated, it is worth noting that dating Byzantine buildings is usually rather difficult, because of the lack of historical documentation, the numerous past interventions, and the current bad conditions of some of these monuments. Thus, their direct study is of utmost importance to take their history further.

\section{Description of the Churches}

Before looking at the analogies and differences between the case study and the Greek churches, it is important to introduce these monuments, in order to better clarify the reasons of the connections among them.

First, it is necessary to know that during the Middle-Byzantine period, churches were characterized by Greek cross plans, where a masonry dome supported by a polygonal drum covered the central naos, located at the intersection of the cross arms. Several variations concern these buildings, according to the dome dimensions and the consequent number of supports.

The octagonal dome type is a particular evolution of the cross-in-square church and in this case, eight pilasters support the main cupola, allowing the transition from the square central space, to the octagonal disposition of the vertical supports, and finally to the circular plan of the dome. More specifically, these pillars sustain eight arches (four semicircular and four embodied in the squinches at the corners) and eight pendentives, above which it is possible to admire the huge drum and the upper cupola.

Hans Buchwald defines these churches as "ingenious solutions"11, where the combination between the basilica scheme and the Greek cross plan is developed.

8. Gabriel Millet, Le Monastère de Daphni [The Daphni Monastery] (Paris: E. Leroux, 1899), 54.

9. Eustathios Stikas, L'Eglise Byzantine de Christianou [The church of Christianou] (Paris: E. de Boccard Editeur, 1951). It is important to underline that the archaeologist, aside from having led the restoration works of the monastery in Triphylia, took part to the redaction of the Venice Chart in 1964.

10. Hans Buchwald, "The Concept of Style in Byzantine Architecture," in Form, Style and meaning in Byzantine Church Architecture, ed. Hans Buchwald, (Alderhot: Ashgate, 1999).

11. ibid., 7. 
There are two main variations of the octagonal dome type: the "mainland octagon" $^{12}$, typically found in relatively few examples in the continental Greece, and the "insular domed octagon"13, mainly developed in some Eastern Greek islands.

In these churches, two different types of squinches allow the transition from the square to the octagon. According to Stikas ${ }^{14}$, squinches with conical shape occur in the monuments located in the Greek mainland, whereas hemispherical niches characterize the inside of the churches of the insular single dome. The first group belongs to the Helladic School, while the second one comes from the Constantinopolitan tradition.

The "mainland octagon" widely developed in the XI century, starting from the church of Hosios Loukas in Phocis. Other churches were built all over the Greek area looking at the prototype: Soteira Lykodemou at Athens, the main church of Daphni Monastery and the basilica of the Transfiguration of Christ in Triphylia (during the XI century); Agia Sophia in Monemvasia, Hagios Nikolaos at Kampia (founded in the XII century); Agioi Theodoroi in Mistra and the Paregoritissa at Arta (built in the XIII century). In these churches, thanks to the presence of the lateral naves around the central naos, the system is confined and the transversal walls can better counteract the main dome thrusts.

The further variation of the octagonal dome type is the single dome octagon plan. The peculiarity of these churches deals with the striking vertical rise of the central naos supported by a slim drum that sustains a masonry dome. As aforementioned, in this case, the transition from the square shape to the octagonal one is allowed by hemispherical niches, which transmit the forces right to the thickness of the perimeter walls. Unlike the first group, because of the lack of the lateral naves, this system is more vulnerable: even the eventual external actions due to catastrophic events such as the seismic ones can easier mine the stability of the building. This problem has brought the master builders to make variations of the single domed octagon plan, which we can find pure only in the architecture of Nea Moni on Chios, and maybe in an archetype that could have been founded in Constantinople ${ }^{15}$.

As previously mentioned, all these buildings may find their Italian corresponding model in Santa Fosca in Torcello ${ }^{16}$.

12. Charalambros Bouras, Byzantine and post-Byzantine architecture in Greece (Athens: Melissa Publishing House, 2001).

13. Charalambros Bouras, "Twelfth and Thirteenth Century Variations of the Single Domed Octagon Plan," Deltion of the Christian Archeology Society. $\Delta \varepsilon \lambda \tau i$ ov XAE 9 (19771979): 21-34. In this study, Bouras finds eight churches that belong to this specific category. More specifically, he identifies some sub-groups, comparing their shapes and finding the differences.

14. Eustathios Stikas, L'Eglise Byzantine de Christianou [The church of Christianou] (Paris: E. de Boccard Editeur, 1951).

15. Charalambros Bouras, "Twelfth and Thirteenth Century Variations of the Single Domed Octagon Plan," Deltion of the Christian Archeology Society. $\Delta \varepsilon \lambda \tau$ tiov XAE 9 (19771979): 27.

16. Even other Italian churches of the XI and XII centuries can be compared to the Greek ones. In Palermo we can find the Martorana, the Palatin Chapel, San Cataldo, and San 
This small church is characterized by a Greek cross plan, where the Eastern arm, namely the presbytery, is twice the length of the others. Each arm is divided in three parts: a barrel vault covers the central nave, whereas the lateral spaces, whose width is half of the central one, are roofed by cross vaults.

As it is possible to see in Figure 1, the red lines trace the rhythm set to the whole structure by eight marble columns, organized in an octagonal shape, which confines the central naos, at the intersection of the cross arms. These columns bear three arches per each side of the square, which becomes an octagon through the presence of four unusual couples of overlapping niches. At the top of these uncommon pendentives, there is a drum with a diameter of about $10 \mathrm{~m}$ and a height of $1.5 \mathrm{~m}$. A conical roof recently restored crowns the central space (Figure 2).

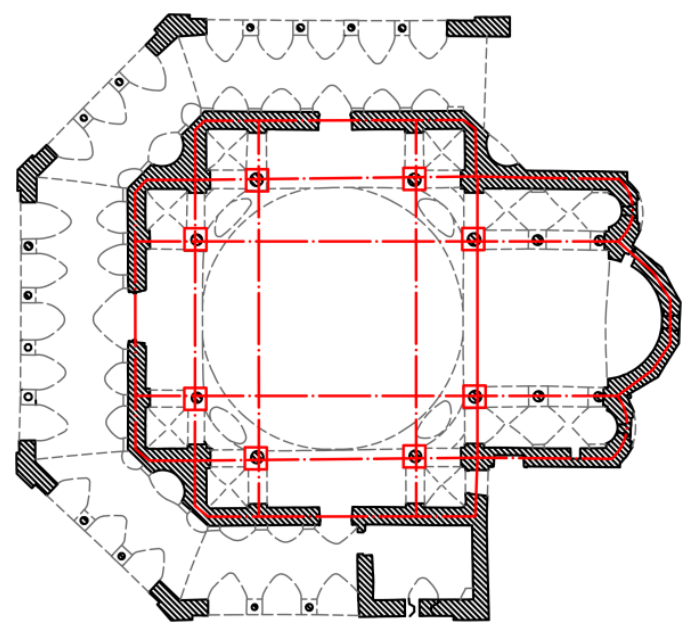

Figure 1. Santa Fosca in Torcello

Source:Author's drawing

Giovanni degli Eremiti. However, these churches show Arabian influences and their squinches assume an ogival shape. Moreover, we can find some examples even in Lombardy, where the Romanic master builders started to introduce in the Latin basilicas a tiburio to crown the intersection of their cross arms. Even in these architectures, we can find the presence of the four squinches that allow the transition from the square to the octagonal plan. Nevertheless, in these buildings the central system is beard only by four massive vertical supports, instead of the usual eight piers. Thus, Santa Fosca is the only Italian survived example of the medieval period, where eight pillars surround the central naos. 


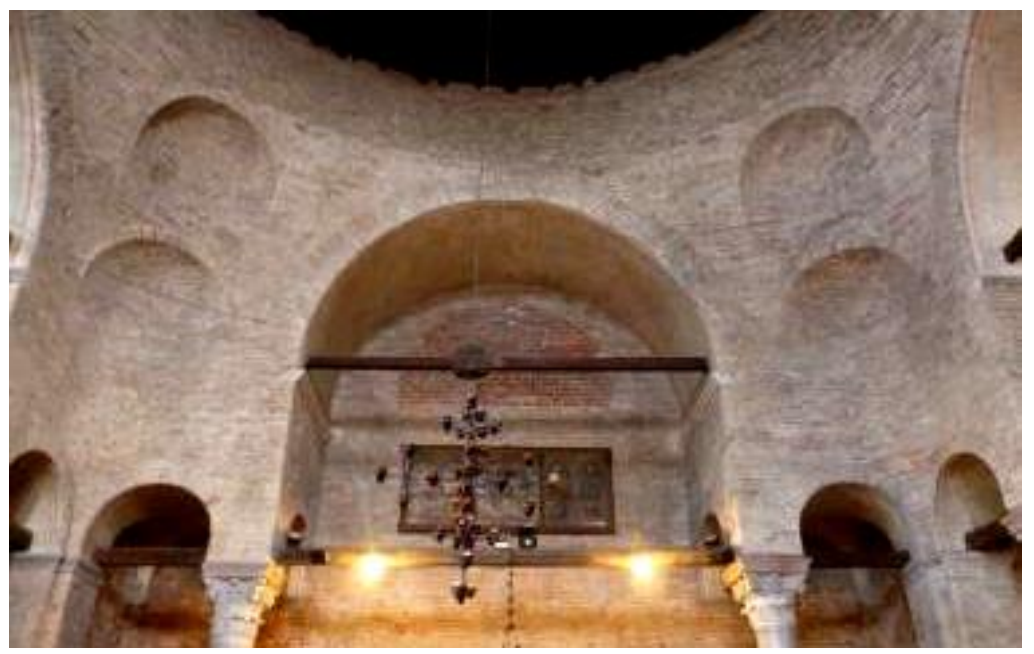

Figure 2. Northern Internal View of the Church Source: Author

Externally, a portico surrounds the church on its Southern, Western and Northern sides and connects Santa Fosca with the main Basilica of Santa Maria Assunta. Furthermore, due to the presence of the porch, it is not so easy to notice the three curious niches located at the N-E, N-W and S-W external corners of the cross plan.

Another interesting feature is the decoration that can be admired on the external side of the central apse (Figure 3).

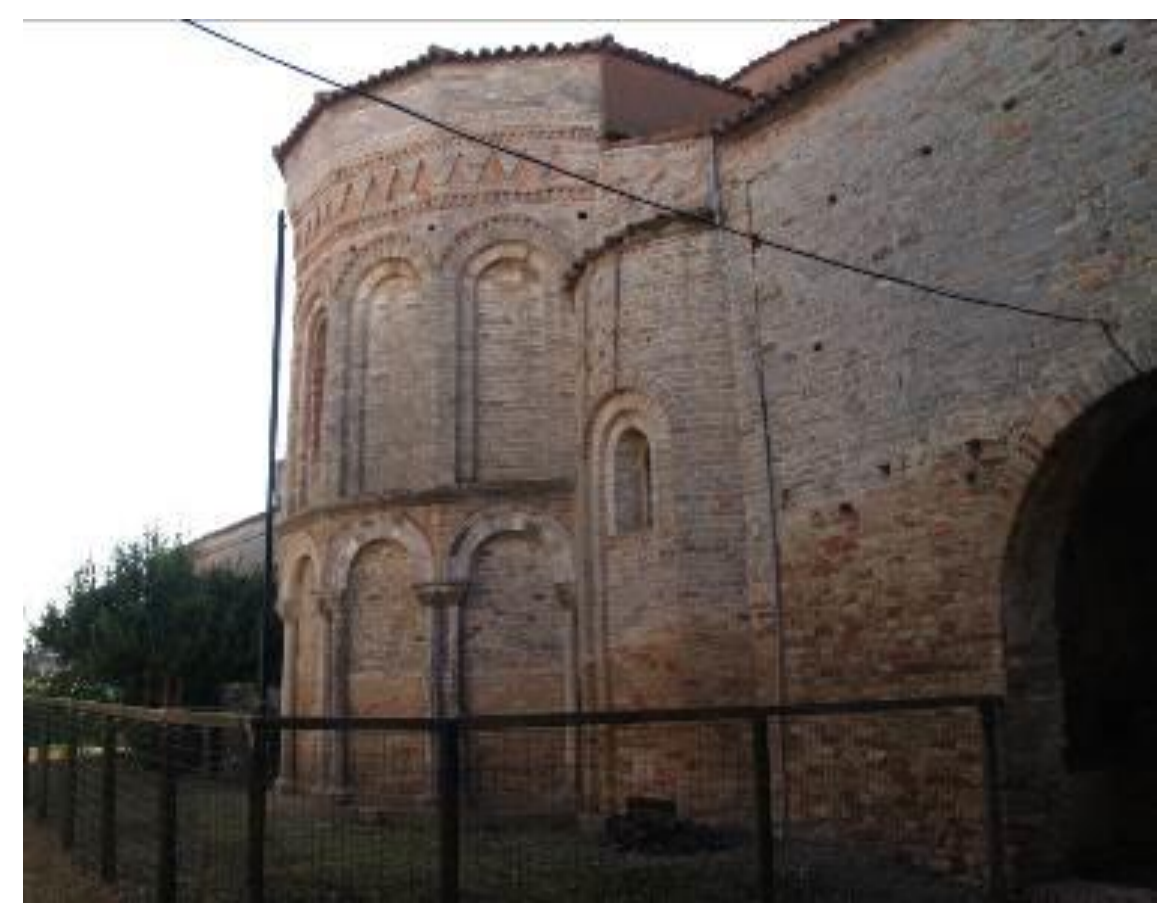

Figure 3. Eastern External View of the Church

Source: Author 


\section{Differences and Analogies}

Starting from the plan views of these monuments, we can find evident analogies between the Italian church and the Greek ones.

More specifically, the relation between the central space and the presbytery in Santa Fosca is very similar to the organization present in the churches of the continental Greece. In Figures 4 and 5, Santa Fosca red scheme has been drawn on four plans belonging to some of the Greek churches we are studying. In Figure 4 (a), we can see that Hosios Loukas and Santa Fosca are very similar in their dimensions: the ratio between the two plans is 1:1.

In the church of the Transfiguration of Christ (Figure 4 (b)), the width of the bema is very similar to Santa Fosca presbytery (even in this case the ratio between the two plans is 1:1), whereas the diakonikon and the prothesis do not have the same width of Santa Fosca lateral apses. However, we should specify that this comparison is not certain, since there could be some doubtful reconstructions of the Eastern side of Santa Fosca during the medieval period.

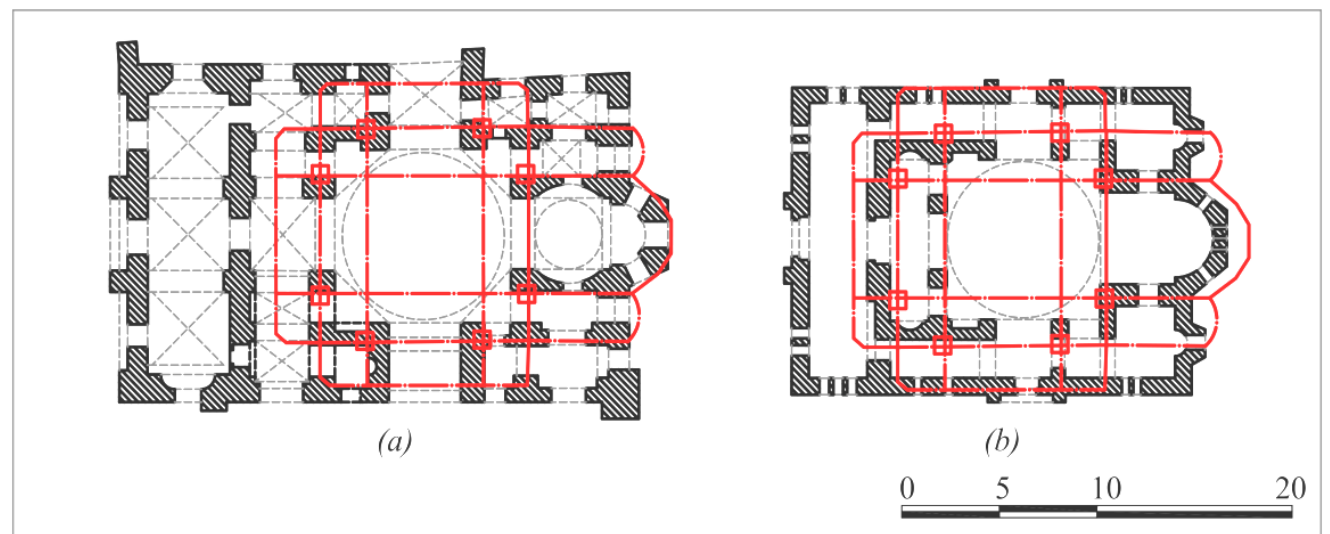

Figure 4. Comparison between Santa Fosca and (a) Hossios Loukas, (b) Church of Transfiguration of Christ

Source: Author's drawing

On the other hand, in Figure 5, the dimensions of the Venetian church red scheme have been reduced, in order to stress the similar proportions between the internal spaces of these two basilicas and the Italian one: the ratio between Santa Fosca and Soteira Lykodemou (Figure 5 (a)) is about 1.5, while with Daphni church (Figure 5 (b)) is approximately 1.25 . Thus, although in this case the dimensions have been diminished, Soteira Lykodemou and Dafni match more than the other two churches. 


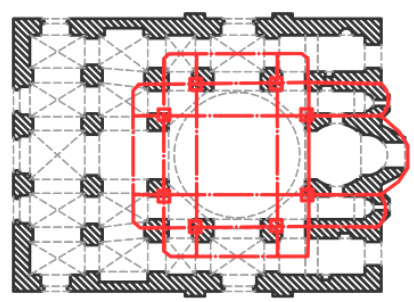

(a)

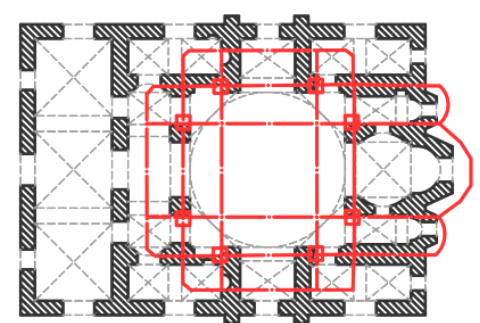

(b)

\begin{tabular}{llll}
$0 \quad 5$ & 10 & 20 \\
\hline
\end{tabular}

Figure 5. Comparison between Santa Fosca and (a) Soteira Lykodemou, (b) Catholicon of Daphni Monastery

Source: Author's drawing

Moreover, it is important to underline that the diameter of the drum of Santa Fosca is the biggest one: in the Venetian church, it is about 10 meters, while in the largest of the Greek churches (namely Hosios Loukas) it is only 8.6 meters.

Furthermore, in Santa Fosca the disposition of the eight central supports is more irregular than the one that occurs in the Greek churches of the mainland, where the pillars form a prefect octagonal plan.

On the contrary, in the insular domed octagon type, the corner sides of the octagon are shorter than the other four, just as in Santa Fosca.

In Figure 6, Santa Fosca red scheme has been drawn above two Chios Island churches (Panagia Krina (a), and Agioi Apostoloi at Pirgy (b)). Even in this case, Santa Fosca red scheme has been reduced: the naos of the Venetian church is almost two times Panagia Krina, and about three times Agioi Apostoloi church. We can note that the Greek island churches show more irregularities than Santa Fosca, and, as we already mentioned, do not have lateral naves.

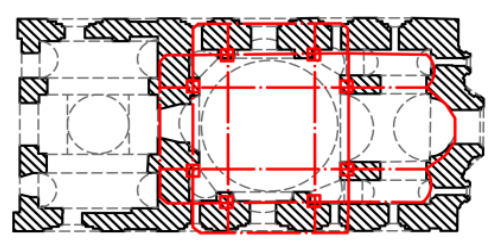

(a)

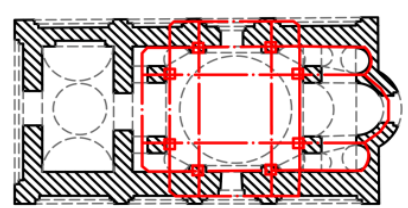

(b)

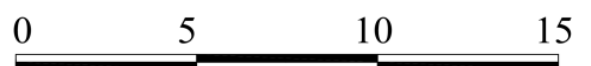

Figure 6. Comparison between Santa Fosca and (a) Panagia Krina, (b) Agioi Apostoloi at Pirgy

Source: Author's drawing 
Nevertheless, because of their hemispherical shape, the squinches of Santa Fosca match better with the ones developed in the islands.

In Figure 7, it is possible to note the similarities between Santa Fosca and Agioi Apostoloi at Pirgy: in both churches, the lateral arches are lower than the central ones and bear the corner niches, which join the same level of the central arches.

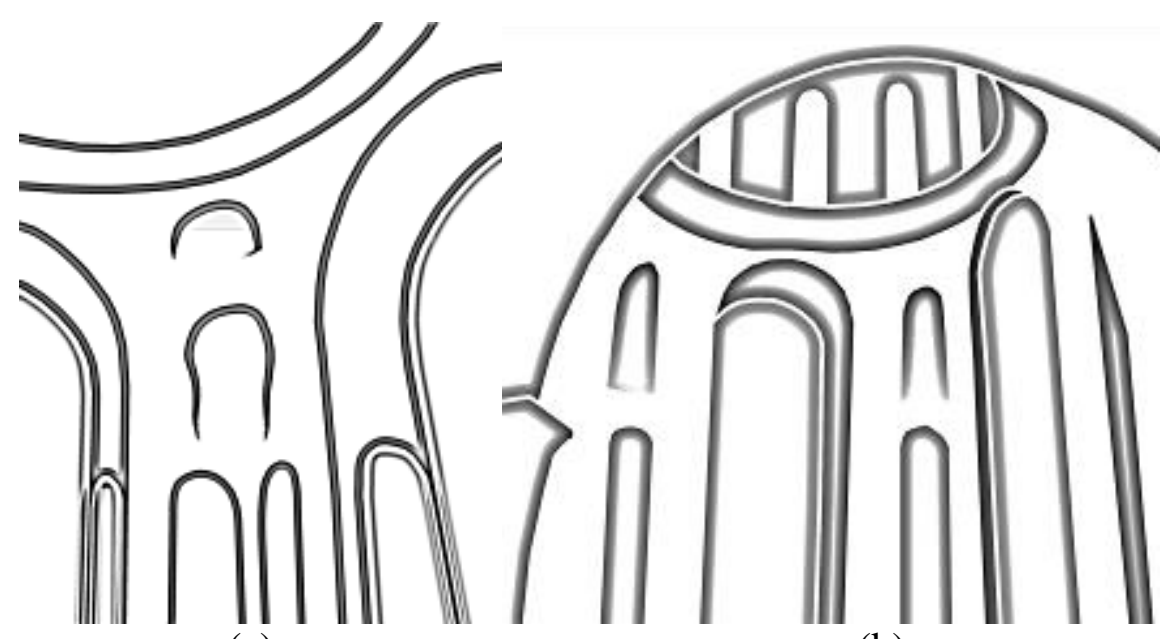

(a)

(b)

Figure 7. Comparison between squinches: (a)Santa Fosca, (b)Agioi Apostoloi Source: Author's drawing

An aspect that makes Santa Fosca different from all the Greek churches concerns the constructive techniques. Re-used bricks characterize its masonry brickwork, according to the local tradition: during the medieval period, it is very common among builders to employ materials taken from preexisting edifices.

Conversely, three leaves usually compose the masonry of the Greek mainland churches, where two external layers made by stones alternating bricks conceal the infill weaker material. Furthermore, a very accurate construction process is visible on both the surfaces of the walls: on the external side, we can appreciate the Byzantine constructive technique of the cloisonné, while golden mosaics, marbles and frescoes cover the inner surfaces ${ }^{17}$. On the other hand, in the small island churches, bricks mostly replace stones, whereas, on the internal side, mainly frescoes occur.

However, it is even worth noting the particular ornament that characterizes the external side of Santa Fosca central apse: tooth-dogs and triangular motives on the upper part and a double order of blind arches below distinguish this portion, where couples of thin white columns are the supports of the arches at the floor plan (see Figure 3 and Figure 8 (a)). This singular decoration can be compared with the apse of the Venetian Basilica di Santi Maria e Donato in

17. It is necessary to underline that these architectures suffered many damages due to catastrophic events, such as earthquakes and wars. Thus, most of them were partly reconstructed, and lost some of their precious cladding. 
Murano, but even with some of the churches of the insular type. Among them, a very similar motive occurs on the external side of the drum of the aforementioned Agioi Apostoloi at Pirgy (Figure 8 (b)). In fact, in these small churches, since the use of stones is mostly absent, bricks generally characterize the external decoration.

However, it is important to underline that this type of bricks is thinner and longer (about $4 \mathrm{~cm}$ thick and $28 \mathrm{~cm}$ long) and the ratio between mortar horizontal joints and brick courses is almost 1:1. Conversely, in Santa Fosca, bricks show various dimensions (since they belong to re-used material coming from preexisting architectures) and the masonry pattern has a completely different construction technique.

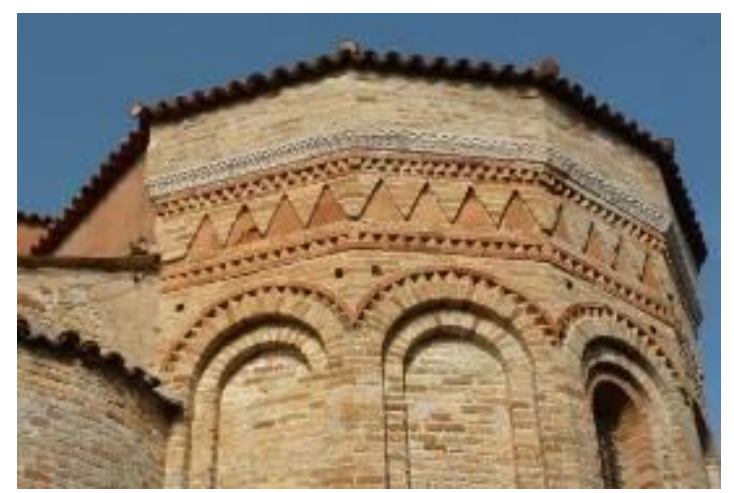

(a)

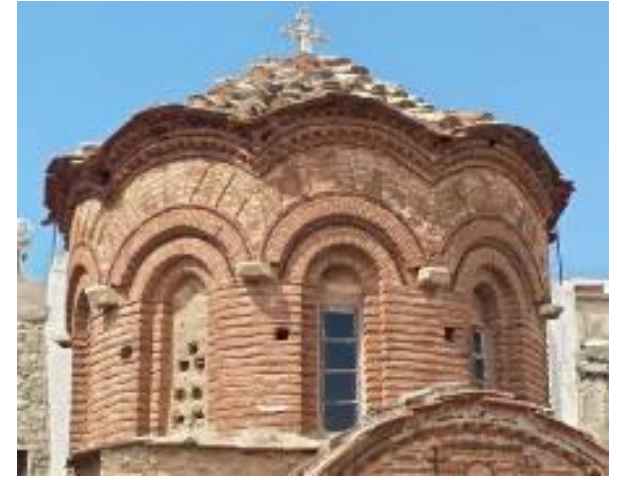

(b)

Figure 8. Decoration of Tooth-Dogs and Triangular Motives: (a) Santa Fosca apse; (b) Agioi Apostoloi Drum

Source: Author's pictures

\section{Dating Problems}

The history of the origins of Santa Fosca is not yet clear and a large debate still tries to define the period of its erection, as well as the possibility of successive structural modifications that have brought the church to look like nowadays.

The first reliable document that gives us information about Santa Fosca belongs to the $1011^{18}$, when two sisters, Bona and Fortunata, made a donation act in favour of a Church in Torcello dedicated to Saint Fosca.

According to Raffaele Cattaneo, there was a church already in the IX century, a small basilica with three naves concluded by three apses. Around the end of the XI century, this basilica was rebuilt and transformed in a central plan church $^{19}$.

18. Flaminio Corner, Ecclesiae Torcellanae antiquis manumentis nunc etiam primum editis illustratae, Vol. X [Historical news about churches and monasteries of Torcello] (Padua: Stamperia del Seminario, 1749), 93.

19. Raffaele Cattaneo, L'architettura in Italia dal secolo VI al mille circa [Italian architecture since about VI to XI century] (Venice: Ongania, 1889), 264. 
When Sergio Bettini considers the hypothesis of a church before the XI century, he assumes that it was characterized by a simple cross plan, which gave the idea of a martyrion. In support of this argument, he compares Santa Fosca to the mausoleum of Galla Placida in Ravenna, which is used as example to explain the exarcal feature of the complex of Torcello ${ }^{20}$. In the same occasion $^{21}$, Ferdinando Forlati, who led the restoration works on the church, asserts that there were no substructures under the visible ones and assumes that the nowadays construction belongs to the original one, namely a central plan with a deep arm containing the three apses.

Maurizia Vecchi ${ }^{22}$, who agrees with Bettini's opinion of a previous martyrium, is sure of the existence of Santa Fosca at least two centuries before the famous document of 1011: three documents belonging to the IX century mention an ecclesia sanctae Fuscae located in comitatu vicentino. Conversely, Wladimiro Dorigo justifies those citations as a mere coincidence, discrediting this hypothesis ${ }^{23}$. The excavations on Torcello that took place during the second half of the last century ${ }^{24}$, give important information about the ancient conditions of the complex. Specifically, in the area facing the building of Santa Fosca they discovered some skeletons, dated approximately about X century. This proved that in ancient times the area was a cemetery ${ }^{25}$. These assumptions are only few of the several hypotheses that characterise the complex debate that concerns the obscure origins of Santa Fosca.

Dating problems involve even the Greek churches: it is unknown the certain foundation date of some of these monuments.

Scholars agree that they were built starting from the XI century. According to the most recent hypotheses, the Katholikon of Hosios Loukas is the prototype, and it was founded between the 1011 and the $1025^{26}$. More specifically, according to Chatzidakis, it was built in $1022^{27}$.

20. Sergio Bettini, "Aspetti bizantineggianti dell'architettura di Torcello" [Byzantine features of the architecture of Torcello] in Torcello, ed. Mario Brunetti et al. (Venice: Libreria Serenissima Editrice, 1940), 54-55.

21. The book contains both the just mentioned intervention of Bettini and the one of Ferdinando Forlati, "L'architettura a Torcello" [Architecture on Torcello] in Torcello, ed. Mario Brunetti et al. (Venice: Libreria Serenissima Editrice, 1940), 118.

22. Maurizia Vecchi, "Santa Fosca di Torcello prebizantina" [Early Byzantine Santa Fosca of Torcello] Atti dell'Istituto Veneto di Scienze Lettere ed Arti, CXXXV, (1977): 283. Other studies led by the scholar are in Maurizia Vecchi, Torcello, Ricerche e Contributi [Torcello, research and contributions] (Rom: "L'Erma" di Bretschneider, 1979), 25-29, and in Maurizia Vecchi, Torcello. Nuove Ricerche [Torcello. New research] (Rom: "L'Erma" di Bretschneider, 1982), 57-70.

23. Wladimiro Dorigo, Venezia origini: fondamenti, ipotesi, metodi [Origins of Venice: bases, hypotheses, methods] (Venice: Electa, 1983), 520.

24 Lech Leciejewicz, Eleonora Tabaczynska, Stanisław Tabaczynski, Torcello. Scavi 1961-62. [Torcello. Escavations 1961-1962] (Rom: Istituto Nazionale di Archeologia e Storia dell'Arte, 1977).

25. According to the authors of these excavations, the erection of the first S. Fosca could be connected with the burial function.

26. In order to become acquainted with the reasons of this fundamental assumption see the aforementioned essay Paulos M. Mylona, Mone tou Hosiou Luka tou Steiriote: he architektonike ton tessaron naon [Monastery of Hosios Loukas the Stiriotis: architectural 
Even the Byzantine Monastery of Daphni is widely admitted to be built in the 11th century, although these assumptions are based only on the morphological evolution theories of architecture and decoration, since no document has been saved before the 12 th century ${ }^{28}$.

Soteira Lykodemou erection is dated between the 1011 and the $1031^{29}$, whereas the first known document that mentions the Church of Christianou in Triphylia is an act of the Patriarch of Constantinople in $1086^{30}$.

On the other hand, concerning the dating of the islands churches, we should first refer to the prototype of Nea Moni in Chios, completed in 1055, when Constantine IX Monomachos died ${ }^{31}$. Thus, none of these churches was erected before the 2 nd half of the XI century. More specifically, the three small churches in Chios are dated stating from the end of the XI century.

\section{Conclusions}

As already mentioned, it is very complicated to date medieval monuments: in this brief dissertation, we have tried to give more information about Santa Fosca origins through the knowledge of the Greek monuments.

A direct or indirect connection between Santa Fosca in Torcello and the Greek churches, in fact, does exist. First, the analogies have been shown throughout this work, and second, several scholars have also studied the affinities between the mosaics of the adjacent Basilica of Santa Maria Assunta in Torcello and the ones that occur in Hosios Loukas, Dafni and Nea Moni ${ }^{32}$.

Several uncertainties still characterize Santa Fosca origins. On the other hand, the presence of ancient documents and well-preserved conditions give a deeper insight on the history of monuments in the mainland Greece. In fact, we can assert that the first monument belonging to this type was erected after the 1011 that is also the date of the first reliable document where Santa Fosca church is mentioned.

analysis of the four churches] (Athens: Grapheio demosieumaton tes Akademias athenon, 2005).

27. Manoles Chatzidakis, "À propos de la date et du fondateur de Saint-Luc" [About the dating and the founder of Saint Luke], CArch 19 (1969), 127-150 and 22 (1972), 87.

28. Nikos Delinikolas et al., Study on the restoration of the Katholikon of Dafni Monastery: Phase A-Architectural and historical survey (Athens: Hellenic Ministry of culture (in Greek).

29. Charalambros Bouras, "The Soreira Lykodemou at Athens. Architecture", Deltion of the Christian Archeology Society. Tó $\mu$ o KE' (2004): 11-24. The terminus post quem has been established from the assumption that the Soteira Lykodemou is a copy of Hosios Loukas.

30. Eustathios Stikas, L'Eglise Byzantine de Christianou [The church of Christianou] (Paris: E. de Boccard Editeur, 1951).

31. Charalambros Bouras, Nea Moni on Chios. History and Architecture (Athens: Commercial Bank of Greece, 1982).

32. Clementina Rizzardi, "La decorazione musiva: Torcello e la cultura artistica mediobizantina" [The musive decoration: Torcello and the Middle-Byzantine artistic culture], in Torcello alle origini di Venezia tra Occidente e Oriente, ed. Gianmatteo Caputo and Giovanni Gentili (Venice: Marsilio, 2010), 60-85. 
Thus, starting from this document and recalling the analogies between Santa Fosca and the Greek churches discussed throughout this work, two alternative conclusions can be drawn.

By assuming that the document refers to the current configuration, it can be first stated that Santa Fosca was built before the important Katholikon of Hosios Loukas and maybe it does not have any direct connection with the Greek churches of the octagonal dome type. The analogies highlighted in this work, however, noticeably pave the way to the intriguing hypothesis that both monuments could refer to an earlier construction, perhaps located in Constantinople.

On the other hand, if the document of 1011 refers to a previous construction located on the same site of the current Santa Fosca, the present Venetian church is not the first one ${ }^{33}$. In this case, Hosios Loukas could have influenced the current configuration of Santa Fosca church.

The latter scenario seems to be more feasible. In fact, within this framework, the unusual features that occur in the Venetian church could be due to the presence of a preexistent structure that could have influenced the scheme of the new construction, which is the current one, built following the MiddleByzantine organization of the octagonal dome plan. In this way, we can also explain the particular Greek cross plan disposition completely different from the one that characterizes the plans of the mainland and even of the islands churches here studied. Moreover, the existence of an earlier structure can justify the presence of the singular couples of squinches that dominate the inside: the previous construction influenced the plan scheme, and the unusual squinches have been designed to allow the transition from the octagon to the circle, otherwise impossible $\mathrm{e}^{34}$.

Without claiming to be exhaustive, the present study offers a new perspective to investigate the obscure origins of Santa Fosca church.

Ongoing comparisons with some other churches located in Greece and even in Asia Minor and in situ detailed observations will complete these preliminary remarks and may better highlight the whole subject concerning the period of construction of this important monument.

\section{Acknowledgments}

Our thanks to Patriarcato di Venezia, for allowing us to use the inside views and the drawings of Santa Fosca church.

33. In this case, we can agree with the scholars we have previously mentioned.

34. Joan Olivia Richardson wrote this hypothesis in her aforementioned contribution on Santa Fosca: Joan Olivia Richardson, "Elementi bizantini nell'architettura delle chiese di San Marco, di Santa Fosca di Torcello e del Duomo di Jesolo" [Byzantine elements in the church architecture of Saint Mark, Santa Fosca of Torcello and the Dome of Jesolo], in Storia dell'arte marciana: l'architettura, ed. Renato Polacco (Venice: Marsilio Editori, 1997), 182. 


\section{Bibliography}

Bettini, Sergio. "Aspetti bizantineggianti dell'architettura di Torcello" [Byzantine features of the architecture of Torcello]. In Torcello, edited by Mario Brunetti, Sergio Bettini, Ferdinando Forlati, and Giuseppe Fiocco, 43-72. Venice: Libreria Serenissima Editrice, 1940.

Bouras, Charalambros. "Twelfth and Thirteenth Century Variations of the Single Domed Octagon Plan." Deltion of the Christian Archeology Society. $\Delta \varepsilon \lambda \tau i$ v XAE 9 (1977-1979): 21-34.

Bouras, Charalambros. Nea Moni on Chios. History and Architecture. Athens: Commercial Bank of Greece, 1982.

Bouras, Charalambros. Byzantine and post-Byzantine architecture in Greece. Athens: Melissa Publishing House, 2001.

Bouras, Charalambros. "The Soreira Lykodemou at Athens. Architecture." Deltion of the Christian Archeology Society. Tó $\mu$ os KE' (2004): 11-24.

Buchwald, Hans. "The Concept of Style in Byzantine Architecture." In Form, Style and meaning in Byzantine Church Architecture, edited by Hans Buchwald, 1-11. Alderhot: Ashgate, 1999.

Cattaneo, Raffaele. L'architettura in Italia dal secolo VI al mille circa [Italian architecture since about VI to XI century]. Venice: Ongania, 1889.

Charton, Edouard. "Les Eglises de Torcello" [The churches of Torcello]. Le Magasin Pittoresque XL Anne (1872): 97-99.

Chatzidakis, Manoles. "À propos de la date et du fondateur de Saint-Luc" [About the dating and the founder of Saint Luke]. CArch 19 (1969), 127-150 and 22 (1972).

Corner, Flaminio. Ecclesiae Torcellanae antiquis manumentis nunc etiam primum editis illustratae, Vol. X [Historical news about churches and monasteries of Torcello]. Padua: Stamperia del Seminario, 1749.

Corroyer, Edouard. L'Architecture Romane [The Romanic architecture]. Paris: Sociétè Francaise d'Edition d'Art, 1888.

Delinikolas, Nikos, Androniki Militadou-Fezans, Efi Chorafa, Eleni Zeroyianni. Study on the restoration of the Katholikon of Dafni Monastery: Phase AArchitectural and historical survey. Athens: Hellenic Ministry of culture, 2003 (in Greek).

Dorigo, Wladimiro. Venezia origini: fondamenti, ipotesi, metodi [Origins of Venice: bases, hypotheses, methods]. Venice: Electa, 1983.

Forlati, Ferdinando. "L'architettura a Torcello" [Architecture on Torcello]. In Torcello, edited by Mario Brunetti, Sergio Bettini, Ferdinando Forlati, and Giuseppe Fiocco, 103-154. Venice: Libreria Serenissima Editrice, 1940.

Krautheimer, Richard. Early Christian and Byzantine Architecture. Harmondsworth: The Pelican History of Art, 1965.

Leciejewicz, Lech. Tabaczynska, Eleonora and Stanisław Tabaczynski. Torcello. Scavi 1961-62. [Torcello. Escavations 1961-1962]. Rom: Istituto Nazionale di Archeologia e Storia dell'Arte, 1977.

Lorenzoni, Giovanni. "Santa Fosca di Torcello nell'ambito architettonico orseoliano" [Santa Fosca of Torcello in the Orseolian architectural field]. In Storia dell'arte marciana: l'architettura, edited by Renato Polacco, 123-131. Venice: Marsilio Editori, 1997.

Millet, Gabriel. Le Monastère de Daphni [The Daphni Monastery]. Paris: E. Leroux, 1899. 
Mylona, Paulos M. Mone tou Hosiou Luka tou Steiriote: he architektonike ton tessaron naon [Monastery of Hosios Loukas the Stiriotis: architectural analysis of the four churches]. Athens: Grapheio demosieumaton tes Akademias athenon, 2005. (in greek)

Richardson, Joan Olivia. "Elementi bizantini nell'architettura delle chiese di San Marco, di Santa Fosca di Torcello e del Duomo di Jesolo" [Byzantine elements in the church architecture of Saint Mark, Santa Fosca of Torcello and the Dome of Jesolo]. In Storia dell'arte marciana: l'architettura, edited by Renato Polacco, 176-183. Venice: Marsilio Editori, 1997.

Rizzardi, Clementina. "La decorazione musiva: Torcello e la cultura artistica mediobizantina" [The musive decoration: Torcello and the Middle-Byzantine artistic culture]. In Torcello alle origini di Venezia tra Occidente e Oriente, edited by Gianmatteo Caputo and Giovanni Gentili, 60-85. Venice: Marsilio, 2010.

Selvatico, Piero. Sulla architettura e sulla scultura in Venezia [About architecture and sculpture in Venice]. Venice: P. R. Carpano Editore, 1847.

Stikas, Eustathios. L'Eglise Byzantine de Christianou [The church of Christianou]. Paris: E. de Boccard Editeur, 1951.

Vecchi, Maurizia. "Santa Fosca di Torcello prebizantina" [Early Byzantine Santa Fosca of Torcello]. Atti dell'Istituto Veneto di Scienze Lettere ed Arti, CXXXV, (1977): 275-285.

Vecchi, Maurizia. Torcello, Ricerche e Contributi [Torcello, research and contributions]. Rom: "L'Erma" di Bretschneider, 1979.

Vecchi, Maurizia. Torcello. Nuove Ricerche [Torcello. New research]. Rom: "L'Erma" di Bretschneider, 1982. 
